\title{
Pemberian tugas menulis untuk meningkatkan kemampuan komunikasi matematis tertulis siswa kelas VIII SMPN 12 Malang pada materi teorema pythagoras
}

\author{
Muftihatul Azizah, M. Shohibul Kahfi* \\ Universitas Negeri Malang, Jl. Semarang No. 5 Malang, Jawa Timur, Indonesia \\ *Penulis korespondensi, Surel: muhammad.shohibul.fmipa@um.ac.id
}

Paper received: 01-11-2021; revised: 15-11-2021; accepted: 30-11-2021

\begin{abstract}
This research aims to describe the stages of application of writing tasks in improving the written mathematical communication skills of class VIII SMP students on the subject of the Pythagorean Theorem. Writing task are carried out through stages of mathematical writing. The stages applied are brainstorming, pre-writting, writing, conferencing, editting, and sharing. From the results of the research the application of writing assignments in learning can improve students' written mathematical communication skills. This is evidenced by the percentage of students who achieve good categories increased from cycle I by 70 percent to 80 percent in cycle II. In addition, the results of observing teacher activities and student activities in the first cycle and second cycle are included in the good category.
\end{abstract}

Keywords: writing task; written mathematical communication.

\begin{abstract}
Abstrak
Penelitian ini bertujuan untuk mendiskripsikan tahapan penerapan pemberian tugas menulis dalam meningkatkan kemampuan komunikasi matematis tertulis siswa kelas VIII SMP pada pokok bahasan Teorema Pythagoras. Pemberian tugas menulis dilakukan melalui tahapan menulis matematis. Tahapan yang diterapkan adalah curah pendapat (brainstorming), persiapan menulis (pre-writting), menulis (writting), diskusi kelompok (conferencing), perbaikan (editting), dan berbagi (sharing). Dari hasil penelitian penerapan pemberian tugas menulis dalam pembelajaran dapat meningkatkan kemampuan komunikasi matematis tertulis siswa. Hal ini dibuktikan dengan persentase banyaknya siswa yang mencapai kategori baik meningkat dari siklus I sebesar 70 persen menjadi 80 persen pada siklus II. Selain itu, hasil observasi aktivitas guru dan aktivitas siswa pada siklus I dan siklus II termasuk dalam kategori baik.
\end{abstract}

Kata kunci: tugas menulis; komunikasi matematis tertulis.

\section{Pendahuluan}

Komunikasi merupakan salah satu kemampuan yang harus dikembangkan di dalam proses pembelajaran matematika. Hal ini sesuai dengan NCTM (2000) yang menyarankan beberapa kemampuan yang harus dikembangkan selama proses pembelajaran matematika yaitu problem solving (pemecahan masalah), reasoning and proof (memberikan alasan dan bukti), communication (komunikasi), connection (menghubungkan), and representation (menggambarkan). Ansari (dalam Nuraeni. R \& Luritawaty. IP, 2016) menyatakan bahwa terdapat dua cara untuk mengkomunikasikan suatu ide yaitu secara lisan dan tulisan. Melalui komunikasi, siswa dapat mempertimbangkan dan mengklarifikasi ide-ide matematis mereka, pemahaman mereka tentang hubungan matematis, serta argumen matematis mereka (Ontario Ministry of Education, 2005).

Pentingnya kemampuan komunikasi matematis sebagai salah satu kemampuan yang harus dimiliki siswa dinyatakan dalam Peraturan Mentri Pendidikan dan Budaya No. 64 tahun 2013 yaitu kemampuan mengkomunikasikan gagasan matematika dengan jelas 
merupakan salah satu kompetensi dasar yang harus dimiliki oleh siswa. Dengan mengkomunikasikan ide-ide atau pendapatnya mengenai suatu topik atau masalah matematika siswa akan belajar untuk mengorganisasikan pola pikir secara lisan atau tulisan (Umar, 2012). Akan tetapi, berdasarkan uji pendahuluan yang dilakukan oleh peneliti di kelas VIII B di SMPN 12 Malang diperoleh fakta bahwa masih banyak siswa yang memiliki kemampuan komunikasi matematis tertulis yang rendah.

Berdasarkan hasil wawancara yang telah dilakukan kepada salah seorang guru matematika di SMPN 12 Malang, diketahui bahwa mayoritas pembelajaran yang biasa diterapkan masih bersifat konvensional dan kurang memberikan kesempatan kepada siswa untuk mengungkapkan atau mengkomunikasika pikiran, ide, dan pendapat mereka. Selain itu tugas-tugas yang diberikan masih kurang mendukung siswa untuk mampu mengembangkan kemampuan komunikasi matematis tertulisnya. Oleh karena itu, untuk meningkatkan kemampuan komunikasi matematis tertulis siswa guru harus melakukan perbaikan pada perencanaan pembelajaran yang dirasa menyebabkan siswa memiliki kemampuan komunikasi matematis tertulis yang rendah. Salah satu perbaikan yang harus dilakukan oleh guru adalah dalam pemilihan tugas-tugas yang akan diberikan kepada siswa.

Guru sebaiknya memberikan tugas yang dapat membuat siswa memiliki pengalaman dalam menyampaikan atau menjelaskan suatu konsep matematika. Salah satu tugas yang dapat diberikan adalah tugas menulis. Pemberian tugas menulis dapat melatih siswa untuk lebih memahami konsep matematika. Hal ini dikarenakan dengan mendengarkan, berbicara dan menulis tentang matematika, siswa diminta untuk mengatur, mengatur ulang dan mengkonsolidasikan pemikiran dan pemahaman matematis mereka, serta menganalisis, mengevaluasi dan membangun pemikiran dan strategi matematis orang lain (Walk, G., Congress, M., \& Bansho, 2010).

Dari hasil observasi uji pendahuluan yang menunjukkan masih lemahnya kemampuan komunikasi matematis tertulis siswa kelas VIII di SMPN 12 Malang menjadikan tempat tersebut sebagai lokasi penelitian yang dipilih oleh peneliti dan materi Teorema Pythagoras dipilih karena materi tersebut belum pernah diajarkan kepada siswa kelas VIII di SMPN 12 Malang.

Berdasarkan paparan yang telah disampaikan, peneliti akan melakukan penelitian tindakan kelas dengan memberikan suatu tugas menulis di kelas VIII SMPN 12 Malang dengan judul "Pemberian tugas menulis untuk meningkatkan kemampuan komunikasi matematis tertulis siswa kelas VIII SMPN 12 Malang pada materi teorema pythagoras".

\section{Metode}

Penelitian ini termasuk jenis penelitian tindakan kelas yang bertujuan untuk mendiskripsikan tahapan penerapan pemberian tugas menulis menggunakan tahapan menulis matematis dalam meningkatkan kemampuan komunikasi matematis tertulis siswa kelas VIII SMPN 12 Malang pada materi teorema pythagoras. Proses pelaksanaan penelitian tindakan kelas ini didesain model dari Kemmis \& Taggart (dalam Hendriana \& Afrilianto, 2017) yang terdiri atas empat tahapan, yaitu planning (perencanaan), acting (tindakan), observing (pengamatan), dan reflecting (refleksi). Dalam penelitian ini peneliti memiliki peran sebagai pengamat, perencana, pelaksana, pengumpul data, penganalisis data, serta perancang tindakan. Subjek penelitian ini adalah siswa kelas VIII B SMPN 12 Malang. 
Pada tahap perencanaan, peneliti membuat perangkat pembelajaran dan instrumen penelitian yang akan digunakan. Perangkat pembelajaran yang digunakan dalam penelitian ini berupa rencana pelaksanaan pembelajaran (RPP) yang berisi kompetensi dasar menjelaskan dan membuktikan teorema pythagoras dan tripel pythagoras, serta menyelesaikan masalah yang berkaitan dengan teorema pythagoras dan tripel pythagoras dengan menerapkan pemberian tugas menulis dalam proses pembelajaran; lembar kegiatan siswa (LKS) berisi soal atau permasalahan yang berkaitan dengan materi Teorema Pythagoras dan dilengkapi dengan petunjuk penyelesaian dengan tahapan menulis matematis yang terdiri dari brainstorming (curah pendapat), pre-writing (persiapan menulis), writing (menulis), conferencing (diskusi), dan editing (perbaikan); dan lembar tes yang berisi soal uraian mengenai materi Teorema Pythagoras.

Instrumen penelitian yang digunakan berupa lembar tes, lembar observasi, dan lembar validasi. Lembar observasi terdiri dari lembar observasi aktivitas guru dan lembar observasi aktivitas siswa. Lembar validasi terdiri dari lembar validasi rencana pelaksanaan pembelajaran, lembar validasi lembar kegiatan siswa, lembar validasi soal tes, lembar validasi lembar observasi aktivitas guru, dan lembar validasi lembar observasi aktivitas siswa.

Pelaksanaan tindakan dilakukan sebanyak tiga pertemuan. Tahap tindakan dilakukan dengan menerapkan pemberian tugas menulis dalam proses pembelajaran dan dilaksanakan sesuai dengan jadwal pelajaran matematika siswa kelas VIII SMP semester genap tahun ajaran 2018/2019. Materi yang digunakan yaitu Teorema Pythagoras. Waktu pembelajaram setiap pertemuan akan berlangsung 2 x 40 menit. Proses pembelajaran dilaksanakan dengan mengacu pada RPP yang telah disusun.

Selama proses pembelajaran berlangsung juga dilakukan tahap observasi. Observasi ini dilakukan menggunakan pedoman atau lembar observasi yang sudah disiapkan oleh peneliti. Observer pada penelitian ini terdiri dari satu guru matematika di SMPN 12 Malang dan dua teman sejawat peneliti yang merupakan mahasiswa matematika Universitas Negeri Malang. Observer dalam penelitian ini mencatat setiap kegiatan yang terjadi selama pembelajaran berlangsung. Setelah dilaksanakan tas akhir siklus, peneliti bersama observer melakukan tahap refleksi. Kajian dalam kegiatan refkeksi berupa data hasil obervasi dan hasil tes akhir yang telah dianalisis. Jika hasil yang diharapkan belum tercapai maka akan dilakukan perbaikan lagi pada siklus selanjutnya.

Teknik pengumpulan data dalam penelitian ini menggunakan langkah-langkah yang terdiri dari observasi atau pengamatan langsung, wawancara, tes, dan dokumentasi. Terdapat dua jenis data yang dikumpulkan dan digunakan dalam penelitian ini yaitu data kualitatif dan data kuantitatif. Data kualitatif berupa hasil observasi aktivitas guru dan hasil observasi aktivitas siswa. Sedangkan data kuantitatif berupa hasil pengerjaan siswa terhadap soal tes akhir yang dilakukan pada setiap akhir siklus pembelajaran.

Data kualitatif dianalisis menggunakan teknis analisis data menurut Miles Hubermen (1994) yang terdiri dari reduksi data, penyajian data, dan penarikan kesimpulan. Data kualitatif dianalisis untuk menentukan kevalidan perangkat pembelajaran dan instrumen penelitian, menghitung persentase hasil obervasi aktivitas guru dan siswa, dan menilis kemampuan komunikasi matematis tertulis siswa terhadap hasil tes. 
Dalam penelitian ini terdapat dua kriteria keberhasilan tindakan yang dijadikan acuan keberhasilan, yakni terlaksananya pembelajaran dengan pemberian tugas menulis dikatakan berhasil apabila seluruh observer memberikan nilai dengan kategori minimal "baik" pada lembar observasi guru dan siswa, serta kemampuan komunikai matematis tertulis siswa dikatakan meningkat apabila minimal 75\% siswa dari keseluruhan memperoleh hasil tes akhir siklus dengan kategori minimal "baik". Apabila diakhir siklus penelitian belum memenuhi kriteria tersebut, maka akan dilanjutkan ke siklus berikutnya.

\section{Hasil dan Pembahasan}

\subsection{Hasil}

Pada siklus I diperoleh hasil validasi perangkat pembelajaran dan instrumen penelitian yang termasuk dalam kategori valid. Validasi ini dilakukan oleh satu validator ahli yang merupakan dosen jurusan Matematika Universitas Negeri Malang dan satu validator praktisi yang merupakan salah satu guru Matematika di SMPN 12 Malang.

Pelaksanaan siklus I dilaksanakan dalam tiga pertemuan. Setiap pertemuan berlangsung 2 x 40 menit. Materi yang diajarkan pada siklus 1 yaitu, pada pertemuan pertama, menemukan kembali teorema pythagoras, menentukan solusi dari masalah yang berkaitan dengan teorema pythagoras untuk bangun datar, menentukan jarak dua titik pada bidang koordinat kartesius menggunakan teorema pythagoras, dan menentukan solusi dari masalah yang berkaitan dengan teorema pythagoras dalam kehidupan sehari-hari; pada pertemuan kedua, menemukan hubungan panjang sisi-sisi segitiga dengan jenis segitiga dan menentukan jenis segitiga dengan menerapkan teorema pythagoras; dan pada pertemuan ketiga, diadakannya tes akhir siklus.

Pada pelaksanaan pembelajaran observasi aktivitas guru dan siswa dilakukan oleh tiga observer yang terdiri dari satu guru matematika di SMPN 12 Malang dan dua teman sejawat peneliti yang merupakan mahasiswa Universitas Negeri Malang. Dari hasil observasi diperoleh rata-rata hasil observasi aktivitas guru pada siklus I berada pada kategori baik dengan persentase nilai $82 \%$ dan rata-rata hasil observasi aktivitas siswa juga berada pada kategori baik dengan persentase nilai $82 \%$. Selama pelaksanaan pembelajaran siklus I terdapat beberapa catatan lapangan yang harus diperbaiki diantaranya pengalokasian waktu pembelajaran, suasana kelas yang sulit kondusif di awal pembelajaran, dan adanya siswa yang tidak berkontribusi selama diskusi kelompok.

Pada hasil tes akhir siklus I menunjukkan bahwa dari 30 siswa kelas VIII B, terdapat 9 siswa yang mendapatkan kategori sangat baik, 12 siswa mendapatkan kategori baik, 7 siswa mendapatkan kategori cukup dan 2 siswa mendapatkan kategori kurang baik, sehingga persentase siswa yang memiliki kemampuan komunikasi matematis tertulis minimal baik adalah 70\%. Oleh karena itu, pelaksanaan pembelajaran siklus I belum dapat dikatakan berhasil dikarenakan hasil tes akhir siklus belum mencapai kategori baik.

Pada siklus II diperoleh hasil validasi perangkat pembelajaran dan instrumen penelitian yang termasuk dalam kategori valid. Validasi ini juga dilakukan oleh satu validator ahli yang merupakan dosen jurusan Matematika Universitas Negeri Malang dan satu validator praktisi yang merupakan salah satu guru Matematika di SMPN 12 Malang. 
Pelaksanaan siklus II juga dilaksanakan dalam tiga pertemuan yang setiap pertemuan berlangsung $2 \times 40$ menit. Materi yang diajarkan pada diklus II yaitu, pada pertemuan pertama, menentukan kelompok bilangan tripel pythagoras, menentukan pebandingan sisi pada segitiga siku-siku sama kaki dengan menerapkan teorema pythagoras, dan menentukan panjang sisi segitiga siku-siku sama kaki; pada pertemua kedua, menetukan pebandingan sisi pada segitiga yang bersudut $30^{\circ}, 60^{\circ}$, dan $90^{\circ}$ dengan menerapkan teorema pythagoras dan Menentukan panjang sisi segitiga yang bersudut $30^{\circ}, 60^{\circ}$, dan $90^{\circ}$; dan pertemuan ketiga, diadakannya tes akhir siklus.

Dalam pelaksanaan pembelajaran observasi juga dilakukan oleh tiga observer yang sama seperti pada siklus I yang terdiri dari tiga oberver yaitu satu guru matematika SMPN 12 Malang dan dua teman sejawat peneliti yang merupakan mahasiswa matematika Universitas Negeri Malang. Dari hasil observasi diperoleh rata-rata hasil observasi aktivitas guru pada siklus I berada pada kategori sangat baik dengan persentase nilai $90 \%$ dan rata-rata hasil observasi aktivitas siswa juga berada pada kategori sangat baik dengan persentase nilai $86 \%$. Pada siklus II pelaksanaan pembelajaran juga sudah dirasa lebih baik dibanding dengan siklus I. Hal ini ditandai dengan guru sudah dapat membuat alokasi waktu yang sesuai dengan yang terdapat pada rencana pelaksanaan pembelajaran yang telah dibuat dan siswa sudah lebih aktif dalam pembelajaran dan lebih mudah diarahkan dalam melaksanakan setiap tahapan menulis karena sudah terbiasa dengan tahapan menulis yang diberikan.

Pada siklus II hasil tes akhir menunjukkan bahwa dari 30 siswa kelas VIII B, terdapat 5 siswa yang mendapatkan kategori sangat baik, 19 siswa mendapatkan kategori baik, 5 siswa mendapatkan kategori cukup dan 1 siswa mendapatkan kategori kurang, sehingga persentase secara klasikal siswa yang memiliki kemampuan komunikasi matematis tertulis minimal baik adalah $80 \%$. Sehingga pada siklus II penelitian ini sudah dapat dikatakan berhasil.

\subsection{Pembahasan}

Penerapan pembelajaran dengan pemberian tugas menulis merupakan salah satu inovasi dapat digunakan dalam pembelajaran matematika. Tugas menulis yang dimaksud dalam penelitian ini adalah siswa diminta untuk menuliskan ide atau gagasan mereka dalam menyelesaian masalah yang terkait dengan konsep matematika menggunakan tahapan menulis. Terdapat enam tahapan menulis menurut Curcio dan Neece (dalam Junaedi, 2010) yaitu Brainstorming (Curah pendapat), pre-writing (pra- menulis), writing (menulis), conferencing (berdiskusi), revising and editing (peninjauan kembali dan perbaikan), publising and sharing (publikasi dan berbagi). Pada penelitian ini tahap revising dan tahap publising tidak dituliskan secara langsung. Hal ini dikarenakan pada tahap conferencing secara tidak langsung siswa sudah melakukan peninjauan atau pemerikasaan kembali terhadap hasil pekerjaan siswa secara berkelompok dan pada saat tahap sharing secara tidak langsung siswa juga melakukan tahap publishing dengan menuliskan hasil pekerjaannya di papan tulis.

Dalam pelaksanaan pembelajaran dengan pemberian tugas menulis dilakukan dalam dua siklus. Setiap siklus terdiri dari 3 pertemuan yang didalamnya terdapat kegiatan awal, kegiatan inti, dan kegiatan penutup. Pada kegiatan awal guru menginformasikan kepada siswa mengenai materi yang akan dipelajari hari ini, tujuan yang ingin dicapai, apersepsi dan motivasi agar siswa mengetahui manfaat dari materi yang akan dipelajari dalam kehidupan sehari-hari. Pada kegiatan inti, sebelum siswa mengerjakan LKS dengan menggunakan 
tahapan menulis, guru membentuk kelompok yang terdiri dari 3-4 siswa dengan kemampuan heterogen.

Setelah siswa duduk sesuai kelompoknya, siswa diberikan Lembar Kegiatan Siswa (LKS) untuk masing-masing siswa. Lembar Kegiatan Siswa (LKS) memuat beberapa tugas menulis. Tugas menulis bertujuan untuk mengenalkan aktivitas menulis matematis melalui permasalahan yang berkaitan dengan materi teorema Pythagoras. Tugas menulis memberikan kesempatan kepada siswa untuk menunjukkan pemahaman konsep dari segi keterampilan. Trianto (2002) menyatakan bahwa pemberian tugas menulis dalam pembelajaran di harapkan dapat membuat siswa memiliki keterampilan dalam menulis.

Lembar Kegiatan Siswa dipermudah dengan adanya petujuk pengerjaan tugas yang berfungsi sebagai pengingat tahapan menulis matematis. Siswa dapat mengerti kapan waktu untuk melakukan brainstorming (curah pendapat), pre-writing (persiapan menulis), writing (menulis), conferencing (berdiskusi), dan editing (perbaikan). Tugas menulis difokuskan pada kegiatan menulis matematis melalui tahapan menulis matematis.

Tahapan menulis yang pertama yaitu melakukan brainstorming (curah pendapat) yaitu siswa dalam kelas pada setiap kegiatan pembelajaran melakukan diskusi untuk menghimpun gagasan, pendapat, informasi awal untuk memahami dan mencari gambaran umum startegi penyelesaian masalah. Siswa menerapkan tahapan curah pendapat dengan melakukan diskusi dengan teman satu kelompoknya. Untuk mempermudah siswa dalam melakukan diskusi dan lebih memfokuskan siswa terhadap apa yang harus mereka diskusikan, guru memberikan pertanyaan-pertanyaan yang perlu didiskusikan yang diletakkan pada tahap pre-writing (persiapan menulis). Hal ini dikarenakan siswa belum pernah menyelesaikan permasalahan melalui tahapan menulis matematis sebelumnya.

Tahap menulis yang kedua yaitu pre-writing (persiapan menulis). Pada tahap prewriting siswa diminta agar menuliskan informasi yang terdapat dalam permasalahan meliputi apa yang diketahui dan apa yang ditanyakan, serta menuliskan rencana mereka menggunakan bahasa mereka sendiri atau membuat gambar sesuai dengan permasalahan. Tahapan ini dilakukan karena menurut Albert (dalam Fuehrer, 2009) menulis untuk menjelaskan proses pemikiran mereka adalah salah satu cara untuk membantu menghubungkan ide-ide siswa dengan solusi mereka.

Namun, ketika siswa mengerjakan tugas pertama pada LKS, terlihat ada beberapa siswa yang mengalami kesulitan untuk menuliskan rencana mereka menggunakan bahasa mereka sendiri. Hal ini bisa dapat disebabkan karena siswa belum terbiasa dalam menuliskan rencana mereka menggunakan kalimat mereka sendiri atau juga dapat disebabkan karena siswa belum memahami permasalahan tersebut. Hal ini sesuai dengan pernyataan Diana, Miler L (1992) yang menyatakan bahwa untuk memulai kegiatan menulis dan juga sesuai dengan pernyataan Fuehrer (2009) yang menyatakan bahwa siswa perlu memahami bagaimana menyelesaikan masalah sebelum mereka dapat mulai menulis penjelasan tentang apa yang mereka lakukan untuk menyelesaikan masalah.

Untuk mengatasi kesulitan siswa tersebut guru memberikan petunjuk malalui tanya jawab karena menurut Bunnett (2007) melalui penggunaan pertanyaan oleh guru dan siswa dapat membantu siswa menjadi penulis yang lebih cakap dan mengembangkan pemahaman yang lebih jelas tentang konsep matematika. Kemudian siswa melakukan tahap writing 
(menulis) yaitu menuliskan hasil penyelesaian dari masalah sebagai langkah untuk mengorganisasikan dan mengembangkan ide yang telah dikumpulkannya.

Pada tahap menulis di tugas pertama guru memberikan petunjuk apa saja yang harus dituliskan oleh siswa seperti apa saja yang diketahui dalam permasalahan, apa yang ditanyakan, langkah-langkah penyelesaian, dan kesimpulan dari hasil pengerjaan yang telah dilakukan. Pada tahap ini, ada beberapa siswa yang melakukan kesalahan dalam penulisan simbol. Kemudian guru mengatasi masalah tersebut dengan memberikan contoh penulisan simbol yang benar kepada siswa karena menurut Siebert (2004) salah satu cara untuk membantu murid-muridnya menulis penjelasan yang lebih baik yaitu dengan memberikan beberapa solusi dan berdiskusi dengan seluruh kelas apakah itu penjelasan yang baik dan mengapa.

Tahap selanjutnya yaitu conferencing (berdiskusi) yaitu siswa bersama kelompoknya melakukan diskusi untuk mempresentasikan hasil tulisan setiap anggota kelompok pada tahap menulis dan mendapatkan timbal baik berupa tanggapan serta masukan terhadap hasil tulisan tersebut. Albert (dalam Bunnett, 2007) menemukan bahwa siswa yang bekerja secara kolaboratif dalam kelompok memperoleh lebih banyak wawasan tentang pemikiran matematika mereka sendiri, yang membantu mereka, mengembangkan tanggapan tertulis mereka.

Kemudian pada tahap editing (perbaikan) siswa memperbaiki hasil tulisannya berdasarkan tanggapan dan masukan dari teman satu kelompoknya. Tahap ini dilakukan karena menurut Flores (dalam Bunnett, 2007) penting bagi siswa untuk mengembangkan metode untuk membenarkan atas kebenaran mereka sendiri akan suatu prosedur atau kebenaran suatu fakta. Tahap sharing (berbagi) dilakukan siswa dengan diskusi kelas dimana perwakilan siswa menuliskan hasil perkerjaannya di papan tulis dan kemudian mempresentasikan hasil tulisannya tersebut.

Tahap sharing dilakukan karena menurut Bunnett (2007) melalui mempertanyakan dan menjelaskan siswa dapat mengembangkan pengetahuan matematika mereka sendiri dan menjadi lebih percaya diri pada kemampuan mereka sendiri. Pada kegiatan penutup guru membimbing siswa untuk menyimpulkan kegiatan pembelajaran yang telah dilakukan dengan menggunakan metode tanya jawab dan meminta siswa menuliskan pengetahuan yang telah mereka peroleh di buku catatan. Dalam pelaksanaan penelitian tedapat beberapa kendala yang dialami oleh peneliti.

Kendala pertama yang berkaitan dengan masalah belajar siswa diantaranya siswa tidak terbiasa menuliskan ide atau gagasan mereka untuk menyelsaikan suatu permasalahan yang terrdapat dalam tugas menulis, siswa masih takut salah dan kurang percaya diri dalam menggunakan kata untuk mendiskripsikan hasil pemikirannya. Kendala kedua berkaitan dengan proses pembelajaran diantaranya Waktu yang dibutuhkan siswa untuk berkelompok terlalu lama sehingga membuang buang waktu, Ada beberapa siswa yang tidak memperhatikan saat temannya persentasi, dan Masih ada siswa yang melihat pekerjaan temannya. 


\section{Simpulan}

\subsection{Kesimpulan}

Berdasarkan paparan data, temuan penelitian, dan pembahasan pada bab sebelumnya dapat disimpulkan bahwa penerapan pembelajaran dengan pemberian tugas menulis dapat meningkatkan kemampuan komunikasi matematis tertulis siswa kelas VIII B SMPN 12 Malang. Pelaksanaan pembelajaran dengan pemberian tugas menulis pada mulanya guru membagi siswa ke dalam kelompok secara heterogen dengan masing-masing kelompok terdiri dari 3-4 siswa. Kemudian guru membagikan LKS yang berisi tugas menulis yang harus dikerjakan siswa menggunakan tahapan menulis matematis.

Tahapan menulis matematis yang digunakan terdiri dari Brainstorming (curah pendapat), siswa bersama dengan kelompoknya mendiskusikan tugas berupa soal yang diselesaikan menggunakan teorema pythagoras; Pre-writing (Persiapan menulis), siswa diminta secara individu untuk menuliskan gagasan yang mereka telah diskusikan pada tahap brainstorming dengan menggunakan bahasa mereka sendiri; Writing (Penulisan), siswa menuliskan penyelesaian dari permasalahan yang diberikan berdasarkan rencana yang telah mereka tulis pada tahap pre-writing menggunakan keterampilan dan pengalaman konsep yang telah dimiliki oleh siswa; Conferencing (diskusi), guru meminta siswa secara berkelompok mengecek hasil tulisan mereka pada tahap writing; Editing (perbaikan), siswa diminta untuk melakukan perbaikan berdasarkan tanggapan dan masukan yang diberikan teman satu kelompoknya pada tahap conferencing; dan Sharing (berbagi), siswa mempresentasikan hasil tulisan pada tahap writing di depan kelas.

Penerapan pemberian tugas menulis dalam pembelajaran seperti yang diuraikan di atas dapat meningkatkan kemampuan komunikasi matematis tertulis siswa. Hal ini ditunjukkan dengan terpenuhinya persentase secara klasikal siswa yang mendapat kategori minimal baik pada tes kemampuan komunikasi matematis tertulis yakni $80 \%$. Peningkatan ini juga didukung oleh persentase keterlaksanaan proses pembelajaran yang didapatkan dari hasil lembar observasi aktivitas guru dan lembar observasi aktivitas siswa yang menunjukkan kategori minimal baik dari seluruh observer pada siklus I maupun siklus II. Dua hal tersebut telah memenuhi kriteria keberhasilan tindakan yang telah ditetapkan.

\subsection{Saran}

Berdasarkan hasil penelitian yang telah dilakukan dengan menerapkan tugas menulis dalam pembelajaran dapat dikemukakan saran diantaranya selama proses pelaksanaan pembelajaran perlu memperhatikan manajemen waktu sehingga pembelajaran dapat berjalan efektif dan sesuai dengan RPP yang telah disiapkan, guru diharapkan memiliki strategi yang tepat sehingga dapat membimbing siswa yang kurang berkontribusi dalam kelompok agar lebih aktif dalam kegiatan kelompok, dan karena penerapan pemberian tugas menulis merupakan metode pembelajaran yang lebih mengutamakan kegiatan menulis maka sebaiknya metode ini dilakukan di kelas yang mayoritas siswa dalam kelas memiliki ketertarikan dengan kegiatan menulis agar lebih efektif.

\section{Daftar Rujukan}

Bunnett, R. (2007). Writing in the mathematics classroom: Does It Have an Effect on Students' Mathematical Reasoning?.

Fuehrer, S. (2009). Writing in math class? Written communication in the mathematics classroom. 
Hendriana, Heris dan M.Afrilianto. (2017). Langkah praktis penelitian tindakan kelas bagi guru. Bandung : Refika Aditama

Junaedi, I. (2010). Pembelajaran matematika dengan strategi writing in performance tasks (wipt) untuk meningkatkan kemampuan menulis matematis. Jurnal Kreano, 1(11).

Miles, M. B., \& Huberman, A. M. (1994). Qualitative data analysis: An expanded sourcebook. Sage (Terjemahan oleh Tjetjep Rohendi Rohidi. Analisis Data Kualitatif : Buku Sumber Tentang Metde-Metode Baru Jakarta : Penerbitan Universitas Indonesia).

Miller, L. D. (1992). Writing in mathematics classes. What research says to the science and mathematics teacher. Number 9.

National Council of Teachers of Mathematics (NCTM). (2000). Principles and standards for school mathematics. Reston, VA: NCTM.

Nuraeni, R., \& Luritawaty, I. P. (2016). Mengembangkan kemampuan komunikasi matematik siswa melalui strategi think talk write. Mosharafa: Jurnal Pendidikan Matematika, 5(2), 101-112.

Ontario Ministry of Education. (2005). The ontario curriculum, grades 1 to 8: Mathematics. Queen's Printer for Ontario.

Indonesia, M. P. D. K. R. Peraturan menteri pendidikan dan kebudayaan republik indonesia nomor 64 tahun 2013 tentang standar isi pendidikan dasar dan menengah.

Draper, R. J., \& Siebert, D. (2004). Different goals, similar practices: Making sense of the mathematics and literacy instruction in a standards-based mathematics classroom. American Educational Research Journal, 41(4), 927-962.

Trianto, A. (2002). Pembelajaran keterampilan menulis. Makalah pada lokakarya seminar nasional membaca dan menulis training of trainer (TOT) bagi guru SLTP.

Umar, W. (2012). Membangun kemampuan komunikasi matematis dalam pembelajaran matematika. Infinity Journal, 1(1), 1-9.

Walk, G., Congress, M., \& Bansho. (2010). Communication in the mathematics classroom. Capacity Building Series, Special Edition \#13, September, 1-8. 